\title{
THE POLITICAL CONTENT OF ANTITRUST
}

\section{ROBERT PITOFSKY $\dagger$}

Although the political forces that produced the major antitrust statutes-in 1890, 1914, 1936, and 1950-varied widely, those statutes once enacted have almost always been enforced and interpreted so that economic considerations were paramount. The issue among most serious people has never been whether non-economic considerations should outweigh significant long-term economies of scale, but rather whether they had any role to play at all, and if so, how they should be defined and measured. ${ }^{1}$

There probably has never been a period comparable to the last decade, however, when antitrust economists and lawyers have had such success in persuading the courts to adopt an exclusively economic approach to antitrust questions. In this paper, I will urge a different view. It is bad history, bad policy, and bad law to exclude certain political values in interpreting the antitrust laws. By "political values," I mean, first, a fear that excessive concentration of economic power will breed antidemocratic political pressures, and second, a desire to enhance individual and business freedom by reducing the range within which private discretion by a few in the economic sphere controls the welfare of all. A third and overriding political concern is that if the free-market sector of the economy is allowed to develop under antitrust rules that are blind to all but economic concerns, the likely result will be an economy so dominated by a few corporate giants that it will be impossible for the state not to play a more intrusive role in economic affairs.

This view is not at odds with the central beliefs of both the "Chicago" and "Harvard" schools that the major goals of antitrust relate to economic efficiency-to avoid the allocative inefficiencies of monopoly power, encourage efficiency and progressiveness in the use of resources, and perhaps, on fairness grounds, to maintain price close to cost in order to minimize unnecessary and undesirable accumulations of private wealth. ${ }^{2}$ Because interpretations that ex-

$\uparrow$ Professor of Law, Georgetown University. Subsequent to the preparation and submission of this paper, the author was appointed a commissioner of the Federal Trade Commission.

1 See, e.g., Blake \& Jones, The Goals of Antitrust: A Dialogue on Policy, 65 Colum. L. REv. 377-400, 422-66 (1965); Elzinga, The Goals of Antitrust: Other Than Competition and Efficiency, What Else Counts?, 125 U. PA. L. Rev. 1191 (1977).

2 For a summary of the central attitudes, principles, and spokesmen of the "Chicago" and "Harvard" schools, see Sullivan, Book Review, 75 Colum. L. Rev. 
clude all but economic concerns have lately become so influential, however, it is important to explain why economic concerns, although properly of paramount importance, should not control exclusively.

It can be argued that the political considerations discussed here are ill-defined and incapable of exact or even meaningful definition. Also, it will be difficult to balance vague concepts such as a fear of economic conditions conducive to totalitarianism against the efficiency loss of an industry structure that is disassembled or a series of business transactions that are disallowed. Finally, it may be that when such vague and controversial factors are introduced into antitrust considerations, some enforcement officials and judges will lose sight of the secondary role of these political factors and will distort and misinterpret antitrust policy. There is merit to each of these concerns. But despite the inconvenience, lack of predictability, and general mess introduced into the economists' allegedly cohesive and tidy world of exclusively micro-economic analysis, an antitrust policy that failed to take political concerns into account would be unresponsive to the will of Congress and out of touch with the rough political consensus that has supported antitrust enforcement for almost a century. ${ }^{3}$

\section{Politicar Values}

Those advocating a non-economic dimension to antitrust should be as specific as possible about those concerns that they would include in an enforcement equation. The considerations I believe must be taken into account are described below; with respect to each, examples will indicate those enforcement areas or cases in which such considerations appear to have played a role. Also mentioned briefly are some non-economic considerations that do not have a proper role in antitrust enforcement, although they un-

1214 (1974) (reviewing M. HANDLer, H. BLAKE, R. PITOFsKy \& H. Goldschimm, Trade Regulation: Cases and Materials (1974)).

${ }^{3}$ See Brodley, Potential Competition Mergers: A Structural Synthesis, 87 YarE L.J. 1, $34 \mathrm{n.131}$ (1977). Brodley accumulates a list of scholars who have emphasized the point about the consensus that supports antitrust enforcement. See particularly Hofstadter, What Happened, to the Antitrust Movement, in THe Business EstabiISHMENT 113, 149 (E. Cheit ed. 1964):

What makes it possible to institutionalize antitrust activities . . . is not a consensus among economists as to its utility in enhancing economic efficiency, but a rough consensus in society at large as to its value in curbing the dangers of excessive market power. As in the beginning, it is based on a political and moral judgment rather than the outcome of economic measurement or even distinctively economic criteria. 
doubtedly have influenced and will continue to influence many courts.

\section{A. Fear of Concentrated Economic Power}

If the choice were posed solely between monopoly power achieved individually, solely as a result of efficiencies, and government intervention to prevent concentration, the legislative history of the Sherman Act ${ }^{4}$ and the overwhelming weight of subsequent judicial interpretation would opt for monopoly power. ${ }^{5}$ The most famous judicial statement of the case for a political dimension to antitrust-Judge Learned Hand's explanation in United States $v$. Aluminum Co. of America $[\text { Alcoa }]^{6}$ that "great industrial consolidations are inherently undesirable" for political as well as economic reasons ${ }^{7}$-granted as much by accepting as an absolute defense the explanation that such a market position was brought about solely through superior skill, foresight, and industry. ${ }^{8}$

The issue is rarely posed that way, however. Instead, there is characteristically a legal challenge to business behavior that produced or maintained monopoly power, or to mergers or cartel arrangements that tend to concentrate or coordinate market power, and a defense that the behavior or arrangements are efficient and therefore tend to contribute to consumer welfare.

As will be developed in a subsequent section of this paper, ${ }^{9}$ Congress has in its antitrust enactments-most clearly when it

415 U.S.C. $\$ \$ 1-7$ (1976).

5 See 21 Conc. REc. 3152 (1890) (remarks of Sen. Hoar, speaking on $\$ 2$ ):

[A] man who merely by superior skill and intelligence ... got the whole business because nobody could do it as well as he could was not a monopolist, but that it [monopoly] involved something like the use of means which made it impossible for other persons to engage in fair competition, like the engrossing, the buying up of all other persons engaged in the same business.

See also United States v. E.I. duPont de Nemours \& Co., 351 U.S. 377, 390-91 (1956).

B 148 F.2d 416 (2d Cir. 1945).

7 Id. 428. In a frequently quoted passage, Judge Hand suggested the following congressional motive for the enactment of the Sherman Act:

It is possible, because of its indirect social or moral effect, to prefer a system of small producers, each dependent for his success upon his own skill and character, to one in which the great mass of those engaged must accept the discretion of a few. These considerations, which we have suggested only as possible purposes of the Act, we think the decisions prove to have been in fact its purposes.

Id. 427 .

$8 \mathrm{Id}$.

${ }^{9}$ See text accompanying notes 29-39 infra. 
amended section 7 of the Clayton Act in 195010 - exhibited a clear concern that an economic order dominated by a few corporate giants could, during a time of domestic stress or disorder, facilitate the overthrow of democratic institutions and the installation of a totalitarian regime. That concern about economic power and the desire that it be dispersed complements the general American governmental preference for a system of checks and balances and distribution of authority to prevent abusive actions by the state. The result is a "tilt" in antitrust, usually evidenced by the design of rules limiting the behavior of monopolists or candidates for monopoly power, and limiting concentration by merger in ways that occasionally incur costs in terms of lost efficiencies.

Perhaps a few examples will help make the point more concrete. If General Motors were to announce a merger with IBM or United States Steel with Xerox, and if those mergers were part of a growing merger trend among the top Fortune 200, it seems unlikely that the legality of those transactions would be fully explored from an antitrust point of view solely by an investigation of the extent to which one company bought products from the other or was a potential entrant into the other's product line. Alternatively, suppose that a single wealthy family were to acquire the leading newspaper in each of the twenty largest cities in the United States. One possible response would be enactment of special legislation to head off that development. If a bill were to become bottled up in committee, however, the Sherman Act should be sufficiently flexible to take into account that threat to political values. Finally, the bedrock antitrust rule that efficient, profit-maximizing conduct that would be legal if engaged in by a small company becomes illegal if part of an unreasonably exclusionary program to maintain monopoly power-for example, acquisition and aggressive enforcement of patents ${ }^{11}$ or a sales policy that encourages leasing over purchases ${ }^{12}-$ can only be understood in light of an antagonism to monopoly power because of political concerns and "in spite of possible costs." 18

$10 \mathrm{Ch} .1184, \S 7,64$ Stat. 1125 (1950) (current version at 15 U.S.C. $\$ 18$ (1976)).

11 See, e.g., Kobe, Inc. v. Dempsey Pump Co., 198 F.2d 416 (10th Cir.), cert. denied, 344 U.S. 837 (1952).

12 See, e.g., Greyhound Computer Corp. v. IBM, 559 F.2d 488 (9th Cir. 1977), cert. denied, 434 U.S. 1040 (1978); United States v. United Shoe Machinery Corp., 110 F. Supp. 295 (D. Mass. 1953), aff'd per curiam, 347 U.S. 521 (1954). 1945).

13 United States v. Aluminum Co. of America, 148 F.2d 416, 429 (2d Cir. 
It is impossible, of course, to prove that massively concentrated economic power, or state intervention induced by that level of concentration, is incompatible with liberal, constitutional democracy. Nevertheless, it is remarkable that historical and contemporaneous democracies are almost invariably associated with market systems, while totalitarian regimes (fascist and communist) almost always are not. Professor Lindblom has noted, as a matter of experience if not logic, that there appears to be an underlying common basis for democracy and a market economy, and common characteristics between democracy and a deconcentrated economic system:

[Democracies] are systems of rules for constraining rather than mobilizing authority. They grow out of a struggle to control authority rather than to create it or make it more effective. They are therefore political systems that are, again, like markets. They practice decentralization, diffusion of influence and power, and mutual adjustments so that individuals in small groups rather than national collectivities can strive for whatever they wish. ${ }^{\mathbf{1 4}}$

It is sometimes argued that it is pointless to deconcentrate industries or to prevent increases in firm size in the name of protecting the political process because associations of small firms with a common interest are as effective (perhaps more effective because of the appearance of numbers) as larger business units pressing for particular political goals. A striking initial point about this argument is that there are little or no relevant data one way or another on the question. However, the contention that groups of firms are the equivalent of a single firm in organizing to achieve political goals does fly in the face of what we know about firm behavior in the analogous area of cartel organization. We know that, given a large number of participants, different levels of efficiency and capacity, and different outlooks about the rewards of vigorous competition or cautious cooperation, cartels are notoriously difficult to organize and maintain. ${ }^{15}$ In the absence of contrary evidence, one might reasonably expect that the kind of uniform commitment to a single set of political goals that might constitute some threat to political stability should be much easier to organize, coordinate, and maintain when relatively few different political and economic interests need to be consulted.

14 C. Lindblom, Pourmics and Markets 165 (1977). (1977).

15 See generally L. Sulrivan, HandBook of the LAw of Antitrust 162-63 


\section{B. Reduction in the Range of Private Discretion}

Professors Blake and Jones have written:

Another political objective of antitrust is the enlargement of individual liberty. Not only are we interested in material well-being and distrustful of political power, but we also have a strong libertarian streak. In the absence of strong countervailing considerations, we favor freedom of action and the wide range of choice that freedom implies .... [T] ine individual who wants to be an entrepreneur rather than an employee ought not to have his opportunities restricted by unnecessary barriers to entry, or by trade practices designed specifically to eliminate him from the field. ${ }^{16}$

Part of the reason we prefer a free-market system over authoritarian alternatives is because important economic decisions that have wide public consequences-which products to make, which technologies to use, where and how much to sell-become subject to the discipline of the market. Every firm is relieved to some extent from the unrelenting demands of a market model, but as markets become concentrated, firms larger, barriers to entry formidable, and prospects of takeover or failure remote, existing sellers are more and more removed from that discipline and would-be challengers find themselves excluded from a fair opportunity to compete. ${ }^{17}$

Some of the bank merger cases, ${ }^{18}$ which preserve the opportunity for businessmen to seek alternative sources of capital for investment plans, can be defended on efficiency grounds, but also evidence this concern to disperse decisionmaking authority. Boycott cases in which the Supreme Court has refused to permit groups of sellers to assume an "extra-governmental" role and displace the market mechanism, regardless of the economic justification, are more comprehensible if this set of values is taken into account. ${ }^{19}$ Sim-

16 Blake \& Jones, supra note 1 , at 383-84.

17 This political concern has been described as more capable of explicit statement as a result of recent advances in the theory of managerial behavior. See Brodley, supra note 3, at 35-36. There is an echo of that concern in the legislative history of the Sherman Act, where Senator Hoar described the law's concern as "the sole engrossing to a man's self by means which prevent other men from engaging in fair competition with him." 21 CoNG. REc. 3152 (1890), quoted in United States v. E.I. duPont de Nemours \& Co., 351 U.S. 377,391 n.15 (1956).

18 See United States v. Phillipsburg Nat'l Bank \& Trust Co., 399 U.S. 350 (1970); United States v. Philadelphia Nat'l Bank, 374 U.S. 321 (1963). For a discussion of Philadelphia National Bank, see text following note 67 infra.

19 See, e.g., Fashion Originators' Guild of America v. FTC, 312 U.S. 457 (1941), discussed in Blake \& Jones, supra note 1, at 429-30. 
ilarly, if several leading oil companies not currently in the coal business were to attempt to acquire several leading coal companies, any future decision to develop alternative energy sources, clearly of crucial significance to the national welfare, would be significantly immunized against the discipline of the market. Even if there were some efficiencies to the combination and absolutely no possibility that either company would expand into the product market of the other, an antitrust challenge should incorporate some concern that the welfare of the country is being placed in the hands of a few economically powerful firms and individuals. This is not to imply that non-economic concerns should be dispositive, but only that they are relevant and should be taken into account.

\section{Avoidance of Political Interference}

The Sherman Act was enacted after a decade of unusual labor violence and agrarian unrest culminating in widespread strikes and anarchist agitation..$^{20}$ It was a period during which there was wide discussion of alternative economic systems. Thorelli's study of Sherman Act legislative history reports that at least one major theme of legislative purpose was the desire to improve the free market system in order to head off direct regulation or Marxist solutions. ${ }^{21}$

Similar notions were even more pronounced in the legislative history leading to the enactment of revised section 7 of the Clayton Act in $1950^{22}$ and should continue to be influential today. If a few companies were to grow to dominate most of the major product markets in the United States, it is inconceivable that those companies would be left free of political accountability. At a minimum they would be required to report the details of their operations far more extensively than companies do today, and they would be the subject of constant legislative investigation and oversight. Eventually such companies surely would come under direct governmental

20 See generally T. BRoOKs, ToII AND Trouble 38-71 (1964). For a summary of the historical context of the antitrust statutes, see L. SulIrvan, supra note 15, at 1218-23.

21 H. Thoredir, The Federal Antrtrust Poltcy (1955). In a frequently quoted debate speech, Senator Sherman said: "You must heed their [the voters'] appeal or be ready for the socialist, the communist, and the nihilist. Society is now disturbed by forces never felt before. . . . These combinations already defy or control powerful transportation corporations and reach State authorities." 21 CoNG. Rec. 2460 (1890), cited in H. THORELl, supra, at 180 . See also Blake, Conglomerate Mergers and the Antitrust Laws, 73 CoLUM. L. Rev. 555, 575-76 (1973).

$22 \mathrm{Ch} .1184, \S 7,64$ Stat. 1125 (1950) (current version at 15 U.S.C. $\$ 18$ (1976)). See text accompanying notes 30-34 infra. 
control. An antitrust system that occasionally disregards claims of efficiency, as in the imposition of per se rules against certain kinds of horizontal cartels ${ }^{23}$ or unwillingness to take dubious evidence of efficiencies into account in judging the legality of mergers, ${ }^{24}$ reflects these political concerns.

A level of industrial concentration that would raise a serious threat of provoking state nationalization probably is not present in the economy today. It is debatable whether there has been any significant recent increase in concentration among the top 200 American corporations; even if there were some increase in concentration, foreign competition and the improved ability of firms to market their products at greater distances from their home plants probably means that most markets are at least as deconcentrated today as they were twenty or thirty years ago. As a result, there are relatively few situations today in which a political dimension must be incorporated to explain a result. That need not always be the case, however. Technological developments or changes in world trade patterns may generate fierce pressures toward concentration. It would be unfortunate if the antitrust laws were interpreted so that they would be impotent in future times of stress to play their role as a defense against undue concentration of economic power.

\section{Non-Economic Concerns That Should Be Disregarded}

There are a number of non-economic concerns that can play no useful role in antitrust enforcement. These include (1) protection for small businessmen against the rigors of competition, (2) special rights for franchisees and other distributors to continuing access to a supplier's products or services regardless of the efficiency of their distribution operation and the will of the supplier (a kind of civil rights statute for distributors), and (3) income redistribution to achieve social goals.

In terms of legislative history, these different goals stand on very different bases. There was legislative history leading to the enactment of the Sherman Act and to the amendment of section 7 of

23 See United States v. Trenton Potteries Co., 273 U.S. 392 (1927), in which evidence of reasonable price in defense of a price-fixing cartel was rejected precisely because constant government intervention would be necessary to determine whether prices were indeed reasonable.

24 See FTC v. Procter \& Gamble Co., 386 U.S. 568, 580 (1967) ("Possible economies cannot be used as a defense to illegality. Congress was aware that some mergers that lessen competition may also result in economies but it struck the balance in favor of protecting competition."). 
the Clayton Act in 1950 showing that Congress was concerned with the disappearance of small independent entrepreneurs and their displacement by massive corporations. ${ }^{25}$ In 1936 this was of course a dominant concern of the legislature in enacting the RobinsonPatman Act. ${ }^{26}$ On the other hand, there are many other indications in the legislative history of the Sherman and Clayton Acts, and in the law as interpreted, that the antitrust laws were designed to preserve competition. These twin goals are impossible to reconcile in circumstances in which small business is disadvantaged by true efficiencies of scale. ${ }^{27}$

After decades of agonizing interpretation, a sort of working compromise has been reached, so that the goal of antitrust is to preserve a competitive process even at the cost at times of the disappearance of less efficient small businesses. That solution is defensible in part because policies that would discriminate in favor of small business in pursuit of mythic virtues of smallness would themselves be inconsistent with another set of political values: maintenance of conditions of equality of opportunity for all businessmen through limitations on the range of private discretion. Moreover, preservation of a competitive system, in part through vigorous antitrust enforcement, will protect small business against the use of unfair tactics by larger companies to gain advantages unrelated to superior skill or efficiency of those larger units.

By contrast, there is no obvious theme in the legislative history of any of the antitrust laws that Congress' purpose was to create procedural protection for distributors or, even more farfetched, to achieve income redistribution. Looking beyond legislative history, these non-economic concerns play no useful role because it is not possible to achieve those goals to any significant extent through antitrust interpretation. ${ }^{28}$ Inefficient small businesses will suffer losses regardless of how the antitrust laws are interpreted, and the

25 See note 34 infra.

2615 U.S.C. $\$ \S 13-13 b, 21 a(1976)$.

27 On the promotion of small business enterprises, see Elzinga, supra note 1, at $1196-1200$. written:

28 On using the antitrust laws to achieve income redistribution one author has

The problem of poverty is attributed more often to the low level of education and job skills of the poor, insufficient aggregate demand, the distorted incentives of current welfare policies, drug addiction and alcoholism, racial discrimination, and a cognitive present orientation among the poor that cuts against exchanging present for future satisfaction. Thus, the pursuit of egalitarian income distribution through antitrust enforcement is likely to have limited results.

Id. 1195-96 (footnote omitted). 
income redistribution that can be achieved through antitrust channels is trivial. Moreover, even if Congress were viewed as truly committed to some or all of those goals, they could be achieved more efficiently and with fewer adverse effects through direct subsidy, taxation, and welfare programs.

\section{JUSTIFICATION FOR INCLUSION OF NON-ECONOMIG} CONGERNS

Factors other than strictly economic concerns should be taken into account because the legislative history of the antitrust statutes, in its own right and as interpreted authoritatively in the courts, so requires, because an exclusively economic approach reflects an unrealistically optimistic view of the certainty introduced by that kind of analysis, and because the introduction of non-economic factors does not result in an undue interference with effective enforcement.

\section{A. Legislative History}

The Sherman Act and most of its amendments do not address specific issues of antitrust enforcement. The key terms "restraint of trade" in section 1 of the Sherman Act and "monopolize" in section 2 were not defined, and the legislative history does not reflect consideration of the possibility that unrelieved pursuit of a free-market competitive system might lead to adverse non-economic effects. ${ }^{29}$

This failure to address the efficiency/political-effects trade-off is not hard to understand. Comprehensive antitrust regulation was a new concept to all legislators, and the most authoritative and exhaustive reviews of the legislative history have detected a series of vague and not always consistent strands of legislative intent. ${ }^{30}$ As many have observed, Congress elected generally to leave specific enforcement decisions to the judiciary.

But putting aside the Sherman Act and its admittedly obscure legislative history, can we discern anything with respect to legislative intent from subsequent antitrust statutes? If we can, it seems clear that those subsequent statutes must be interpreted to incor-

29 See 15 U.S.C. $\$ \S 1-2$ (1976).

30 One of these strands involved the desire to avoid the enhancement of prices. See H. THOnELLI, supra note 21 , at 180 . There was also a broader concern that concentrated economic power would undermine the opportunities of individuals and small businessmen. W. Letwin, LaW and Economtc PoLicy IN AMRERCA 59 (1965); H. ThorelLI, supra note 21 , at 180 . It was believed that these effects would eventually undermine a private enterprise system. Id. 227. See generally Blake, supra note 21, at 575-76. 
porate political concerns, and it appears arguable that these subsequent expressions define Congress' vague intentions in earlier enactments. ${ }^{31}$ Specifically, can fair-minded commentators read the legislative history of amended section 7-the most recent major substantive revision of general antitrust policy-and conclude that Congress intended to regulate mergers and joint ventures without taking into account the political consequences of what it perceived to be an ongoing merger movement?

Section 7 outlaws only those mergers the effect of which "may be substantially to lessen competition, or tend to create a monopoly," 32 and thereby fairly establishes the primacy of economic concerns. There is no record that any legislator has suggested that a merger be challenged solely or principally because of an adverse effect on small business, employment opportunities, equitable distribution of wealth, or long-term threats to the stability of the country's democratic process. The question remains, however, whether such factors can be taken into account at all in deciding at what level to draw the line describing unacceptable reductions in competition.

Some of the key passages of section 7's legislative history reveal strong congressional concern with the political implications of mergers; in this era of augmented influence by economists and economically sophisticated lawyers, we seem to have lost sight of

31 Using subsequent legislative history to illuminate the intent of an earlier Congress seems particularly appropriate when we deal with "a comprehensive charter of economic liberty," Northern Pac. Ry. v. United States, 356 U.S. 1, 4 (1958), written with a "generality and adaptability comparable to that found to be desirable in constitutional provisions." Appalachian Coals, Inc. v. United States, 288 U.S. 344,360 (1933). It also seems particularly appropriate because we deal with the "antitrust laws" - an interrelated network of statutes that supplements and amends earlier versions-designed in toto to govern marketplace competition. Cf. United States v. Hutcheson, 312 U.S. 219, 232 (1941) (describing and interpreting the Sherman, Clayton, and Norris-LaGuardia Acts as "interlacing statutes").

A similar situation was presented in Cantor v. Detroit Edison Co., 428 U.S. 579 (1976) in which Mr. Justice Blackmun, concurring in the judgment, found that the Sherman Act's framers never directly faced the question of the extent to which the Sherman Act preempted inconsistent state law. His separate opinion cited a series of subsequent congressional enactments exempting particular kinds of state regulation-fair trade, insurance regulations, and agricultural marketing arrangements-to indicate Congress' earlier "intent" that, absent these special exemptions, these state arrangements would have been superseded by the Sherman Act. 428 U.S. at 607-09 (Blackmun, J., concurring in the judgment). See also Steffel v. Thompson, 415 U.S. 452, 463-68 (1974) (interpreting the Civil Rights Act of 1871, 42 U.S.C. $\$ 1983$, in part by reading a series of subsequent statutes as part of a historical process through which Congress defined the roles of federal and state courts); United States v. Freeman, 44 U.S. (3 How.) 556, 564-65 (1845) ("[I]f it can be gathered from a subsequent statute in pari materia, what meaning the legislature attached to the words of a former statute, they will amount to a legislative declaration of its meaning, and will govern the construction of the first statute.").

3215 U.S.C. $\$ 18$ (1976). 
these attitudes. Consider the statement by Representative Celler, one of the co-sponsors of the amendment, at the time the bill that eventually became section 7 was originally introduced:

I want to point out the danger of this trend toward more and better combines. I read from a report filed with former Secretary of War Royall as to the history of the cartelization and concentration of industry in Germany:

Germany under the Nazi set-up built up a great series of industrial monopolies in steel, rubber, coal and other materials. The monopolies soon got control of Germany, brought Hitler to power and forced virtually the whole world into war.

The report continues:

A high degree of concentration throughout industry fosters the formation of cartels and readily enables a war-minded government to mobilize for hostilities. Such was the history of war preparations in Germany in both World War I and World War II.

Mr. Walter Lippmann, writing in Fortune magazine several years ago, stated correctly:

The development of combinations in business, which are able to dominate markets in which they sell their goods, and in which they buy their labor and materials, must lead irresistibly to some form of state collectivism. So much power will never for long be allowed to rest in private hands, and those who do not wish to take the road to the politically administered economy of socialism, must be prepared to take the steps back toward the restoration of the market economy of private competitive enterprise.

All these warnings must make us pause. ${ }^{33}$

Now consider the following characteristic statement by Senator Kefauver, the other leading sponsor of the bill:

I think we must decide very quickly what sort of country we want to live in. ... The present trend of great 
corporations to increase their economic power is the antithesis of meritorious competitive development. It is no accident that we now have a big Government, big labor unions, and big business. The concentration of great economic power in a few corporations necessarily leads to the formation of large Nation-wide unions. The development of the two necessarily lends [sic] to big bureaus in the Government to deal with them. Local economic independence cannot be preserved in the face of consolidations such as we have had during the past few years. The control of American business is steadily being transferred, I am sorry to have to say, from local communities to a few large cities in which central managers decide the policies and the fate of the far-flung enterprises they control. Millions of people depend helplessly on their judgment. Through monopolistic mergers the people are losing power to direct their own economic welfare. When they lose the power to direct their economic welfare they also lose the means to direct their political future.

I am not an alarmist, but the history of what has taken place in other nations where mergers and concentrations have placed economic control in the hands of a very few people is too clear to pass over easily. A point is eventually reached, and we are rapidly reaching that point in this country, where the public steps in to take over when concentration and monopoly gain too much power. The taking over by the public through its government always follows one or two methods and has one or two political results. It either results in a Fascist state or the nationalization of industries and thereafter a Socialist or Communist state. Most businessmen realize this inevitable result. Certain monopolistic interests are being very short-sighted in not appreciating the plight to which they are forcing their Government. $^{34}$

To some extent, preservation of a competitive process would achieve the goals that were of concern to these spokesmen; hence it is arguable that the statute is responsibly enforced if exclusively economic considerations, including the dispersal of monopoly power achieved other than by patents or economies of scale, are applied. Legislative history focusing on the protection of competition, not

3496 CoNG. REC. 16,452 (1950). A concern that corporate concentration will inevitably diminish individual freedom is hardly an exclusive preoccupation of "populist" legislators. See Elzinga, supra note 1, at 1200 (citing warnings to that effect by Friedrick Hayek and Milton Friedman). 
competitors, supports that view. ${ }^{35}$ But we know that conflicts between political and economic goals do arise-for example, when a merger generating efficiencies contributes significantly to economic concentration in a given market. Is it conceivable that the sponsors of this bill would accept the notion that preservation of efficiencies ought to be treated as paramount? ${ }^{36}$

One might argue that these are the special views of Senators Celler and Kefauver-political hawks on the question of antitrust enforcement-and are not representative of the views of a broad segment of the majority voting in favor of the bill. That is simply not true. A striking feature of the legislative history of amended section 7 was the widely-shared perception of danger to the political well-being of the country and its citizens stemming from the merger movement. ${ }^{37}$ As Professor Bok has reported, "there emerges a common definition of the problem at hand, a common philosophy as to its import, and a common notion, on a very general plane, of what the new act could do about it." 38

Virtually all proponents of the bill who spoke asserted that the merger trend must be blocked because concentrated economic power would lead to increased government control, because freedom would corrode and totalitarianism prosper, and because absentee ownership by large corporations would diminish local initiative and civic responsibility..$^{39}$ Of course, that kind of language is not helpful in deciding whether a merger between two companies of given size in specific markets is legal. Congress in 1950 left those questions to the courts much as it did in 1890 . But to proceed from that start-

35 See Brown Shoe Co. v. United States, 370 U.S. 294, 320 (1962).

36 An alternate way of presenting the same argument is to point out that the Senate and House reports do not expressly indicate an intention to interpret the statute in light of political goals. See S. ReP. No. 1775, 81st Cong., $2 \mathrm{~d}$ Sess. (1950); H.R. REP. No. 1191, 81st Cong., 1st Sess. (1949). Hence, the legislative rhetoric can be passed off as talk about "aims," and the absence of an express commitment to political values in the reports, an expression of Congress' wish to achieve those aims by exclusive pursuit of economic goals.

Silence in the reports on political issues, however, does not necessarily support that view. In fact, the reports were devoted almost entirely to an explication of the technical aspects of the statute-for example, the reason for the deletion of any reference to the effect on competition between the acquiring and acquired firmsand did not refer to problems generated by the occasional trade-off between effciency considerations and political values. Accordingly, it seems fair to look beyond the Senate and House reports to the debates and focus upon the reiteration in those debates of the pervasive theme of concern for the protection of political values.

37 Bok, Section 7 of the Clayton Act and the Merging of Law and Economics, 74 HARV. L. REV. 226, 234-37 (1960).

38 Id. 234.

39 Id. 235-36. The Supreme Court has ratified the view that Congress was intent on stemming a rising tide of concentration because of a threat to noneconomic values. See Brown Shoe Co. v. United States, 370 U.S. 294 (1962). 
ing point to the conclusion that Congress in 1950 would be satisfied with a judicial interpretation that excluded all non-economic concerns-a position advocated largely by scholars who would not themselves regard the merger movement as a serious threat to political values-reflects a striking disregard for the political process.

\section{B. Feasibility of Incorporating Non-Economic Concerms}

Suppose a political component were to be included in an antitrust enforcement equation. Would that introduce chaos into what otherwise would be an orderly, reliable, and predictable regulatory process? Such a result is unlikely. Those opposed to the inclusion of political factors exaggerate the precision of an enforcement approach that incorporates solely economic concerns, and overstate the administrative difficulties and enforcement costs of taking noneconomic concerns into account.

\section{Illusion of Certainty}

Economists and schools of economists disagree on a theoretical level with respect to many crucial antitrust policy issues: Is a vigorous policy of merger prevention justified because cartels are easier to organize and police in a concentrated market? Does vertical integration lead to significant anticompetitive effects? Do massive advertising expenditures diminish or improve opportunities for entry by new firms? Different advocates of the economic approach would answer these and many other policy questions in entirely different ways.

Even if economic theory were clear and consistent, economics provides no system for reliably determining economic effect. We know that a market served by fifteen or twenty firms that is converted by merger to a monopoly or duopoly will produce a different level of price and perhaps efficiency. In contrast, a merger in a ten-firm market between the sixth and eighth firms reduces the total number to nine but allows the combined enterprise to challenge the leaders more effectively. There is no reliable way to determine either the pro- or anti-competitive effect of that merger with anything approaching scientific reliability. As a result, antitrust enforcement along economic lines already incorporates large doses of hunch, faith, and intuition. ${ }^{40}$ 
Another reason that antitrust is something less than a precise science is that so many antitrust questions are factually indeterminate, a condition exacerbated by unavoidable limitations on the judicial process. The recent controversy over the proposed rule that a monopolist does not engage in exclusionary pricing if prices charged are in excess of average variable costs provides an apt example. ${ }^{41}$ Among the reasons advanced for such a rule is that a single bright-line formula will contribute to increased reliability and predictability in enforcement. Many courts, persuaded by those arguments, appear to be adopting the average variable cost formula. ${ }^{42}$

It is of course desirable, all things being equal, to adopt prospective rules that are workable. Nevertheless, few if any experienced litigators believe that proof of average variable cost-with accounting records in the hands of defendants and the inevitable slippage of the discovery process-would be anything but a rough approximation. If the evidence relates to a multi-plant firm and involves complicated problems of allocation of general overhead, it is uncertain that even a rough approximation is achievable. Again, the argument that inclusion of political factors will introduce an element of unpredictability into an otherwise reliable enforcement system seems unrealistic.

\section{Compatibility of Political and Economic Considerations}

Vigorous antitrust enforcement usually serves both economic and political goals, at least as political goals have been defined here. Elimination or containment of monopoly and elimination of unnecessary barriers to entry and unreasonable business practices not only promote economic efficiency but tend to avoid undue concentrations of economic power, to reduce the range of private discretion in the business field, and to minimize the risks of state interference. But unavoidable inconsistencies occasionally do arise, and the question at that point is whether inclusion of political values, reasonably defined and weighted, leads to unacceptable administra-

41 Compare Areeda \& Turner, Predatory Pricing and Related Practices Under Section 2 of the Sherman Act, 88 HARv. L. Rev. 697, 716-18 (1975) with Scherer, Predatory Pricing and the Sherman Act: A Comment, 89 HARv. L. REv. 869, 873-75 (1976) and Williamson, Predatory Pricing: A Strategic and Welfare Analysis, 87 YALE L.J. 284, 286-306 (1977).

42 See, e.g., International Air Indus., Inc. v. American Excelsior Co., 517 F.2d 714 (5th Cir. 1975). 
tive or anti-efficiency costs. That depends on how political values are introduced into the antitrust equation.

\section{Political Fagtors Applied}

\section{A. Some General Limits}

It has been argued that if political concerns are to be satisfied, there is no clear stopping place short of atomistic competition..$^{43}$ That position overstates the difficulties of introducing political values to leaven what would otherwise be an exclusively economic analysis of antitrust problems.

Political concerns ought to be treated as limited factors that influence the way in which prospective rules are designed to accomplish antitrust objectives. If the rules themselves are clear, introduction of a political dimension will not generate undue uncertainty in enforcement. Moreover, because these political concerns are clearly and expressly secondary, major dislocations in competitive policy will be avoided. ${ }^{4}$

The following sections will indicate how political considerations have properly influenced the development of prospective rules with respect to horizontal mergers, an area of major significance in antitrust enforcement.

\section{B. Political Factors in Horizontal Merger Enforcement}

There is a consensus among economists and antitrust lawyers that mergers among competitors should be prohibited when they lead to concentration, because explicit collusion is more difficult to detect and tacit collusion more likely to occur in concentrated

43 See Bork, The Rule of Reason and the Per Se Concept: Price Fixing and Market Division, 74 YALE L.J. 775, 831-32 (1965).

44 Perhaps political concerns also can legitimately serve as a tie-breaker in individual cases. For example, they may contribute to a finding of illegality with respect to a merger of two very large companies when there are neither significant anticompetitive effects nor significant efficiencies as a result of the merger. It is hard to believe the Supreme Court decision in United States v. E.I. duPont de Nemours \& Co., 353 U.S. 586 (1957) [duPont-GM], in which the Court ruled that duPont's competitors in the automotive finishes and fabrics market were foreclosed from that market because of the close relationship between duPont and GM (which could have been the reason for GM's purchasing most of its requirements from duPont), is not explained in part by the idea that those two companies were regarded as "too big" and "too influential" from a political point of view.

A problem with that kind of enforcement approach is that it is ad hoc with respect to specific transactions and may be unfair to the parties. Unfairness is particularly pronounced if private treble damage exposure must be taken into account. 
markets. ${ }^{45}$ There is also general agreement that cartels are inherently unstable, but that stability can be increased (and the costs of cartel administration decreased) if the number of sellers of competing products, and hence the number of potential defectors from the cartel, is reduced. ${ }^{46}$

Against that policy background, several crucial policy issues relating to horizontal mergers arise: First, what is the minimum level at which a lessening of competition or a tendency toward monopoly will occur as a result of mergers? Second, assuming a merger produces significant anticompetitive effects, should countervailing competitive effects in another market be taken into account in measuring the net competitive effect of a merger? Third, to what extent and in which circumstances will merger rules be modified to take into account efficiencies resulting from the merger?

Although the law on these questions may be in a state of flux, it is likely that the minimum levels at which mergers can be challenged successfully remain in the five-to-ten-percent range, at least when markets are moderately or highly concentrated. ${ }^{47}$ The courts will not consider evidence of redeeming competitive effects in another market. ${ }^{48}$ Efficiencies resulting from a merger are taken into account as a preliminary matter in that horizontal mergers, despite their inevitable price and market allocation effects, are not judged under a per se standard, but evidence of efficiency is probably irrelevant under present law as a defense to any specific merger. ${ }^{49}$ This analysis assumes that the misstep in the earlier Brown Shoe ${ }^{50}$ opinion suggesting that efficiencies of integration might be a reason for striking down a merger, ${ }^{51}$ is no longer good law. ${ }^{52}$

45 See, e.g., G. Stiglen, A Theory of Oligopoly, in Trie Organtzatron of INDUSTRY 39 (1968); Hearings on Economic Concentration Before the Subcomm. on Antitrust and Monopoly of the Senate Comm. on the Judiciary, 89th Cong., Ist Sess. 540-51 (1965) (statement of Professor Carl Kaysen).

46 See Weiss, The Concentration-Profits Relationship and Antitrust, in Industriar Concentration: The New Learnang 189-93, 231 (Goldschmid, Mann \& Weston eds. 1974) (summarizing relevant economic literature on the subject).

47 See United States v. Von's Grocery Co., 384 U.S. 270, 272 (1966) (combined market share of 7.5\% outlawed); Brown Shoe Co. v. United States, 370 U.S. 294, 343-14 (1962) (combined market shares of 5\% outlawed on ground that it would require the courts to approve future mergers of similar market shares, thus leading to the oligopoly Congress sought to avoid); Merger Guidelines of Dep't of Justice, 1 Trade Reg. ReP. (CCH) \4510, §\$ 5-6 (1968).

48 United States v. Philadelphia Nat'l Bank, 374 U.S. 321, 370 (1963).

49 See Ford Motor Co. v. United States, 405 U.S. 562, 569-71 (1972); Merger Guidelines of Dep't of Justice, 1 Trade Reg. Rep. (CCH) $\llbracket 4510, \S 10$ (1968). See also FTC v. Procter \& Gamble Co., 386 U.S. 568, 580 (1966). But see Sullivan, supra note 15 , at 631.

50 Brown Shoe Co. v. United States, 370 U.S. 294 (1962).

51 Id. 344.

52 See Blake \& Jones, supra note 1, at 455-57. 
When scholars who advocate antitrust enforcement aimed exclusively at serving economic goals contemplate these rules, they understandably are driven to conclude that the rules are wrong, the policies misguided, and the legislators and judges who impose them unsophisticated or ill-informed..$^{53}$ A merger producing a combined market share of five percent could occur in a market with scores of other sellers. Even taking the "incipiency" dimension of section 7 into account, it is doubtful as a matter of economic analysis that one could predict that a reduction in sellers from twenty to nineteen or even from fifteen to fourteen-except in special and unusual circumstances-would substantially increase the likelihood of tacit or overt collusion. It is also difficult for those who demand antitrust enforcement solely to achieve allocative efficiency and optimum levels of firm size to comprehend an enforcement policy that refuses to permit as a defense lines of evidence that show directly that these very effects are likely to be achieved by a particular merger. On the other hand, those who support incorporation of non-economic considerations in antitrust enforcement may have some reservations about specific cases and rules, but can generally support the current lines of authority described above. ${ }^{54}$ The reasons for that support differ and are illuminating in indicating the ways in which the "political" thinkers part company with homo economicus.

\section{Threshold Level of Illegality}

Measured solely by economic concerns, formidable arguments can be advanced that no merger ought to be prevented unless it produces market concentration in which the top four firms account for more than sixty percent of the market. ${ }^{55}$ Advocates claim that this rule would leave ample opportunity to achieve by merger optimum levels of scale, and would not introduce any serious likelihood of tacit collusion. ${ }^{56}$

53 Bork, The ANtitrust Paradox 200-04 (1978); Bowman, Contrasts in Antitrust Theory II, 65 CoLOM. I. Rev. 417, 418 (1965) ("Application of oligopoly analyses to market situations such as existed in the Brown Shoe case is grotesque.") (citation omitted); Posner, Antitrust Policy and the Supreme Court: An Analysis of the Restricted Distribution, Horizontal Merger and Potential Competition Decisions, 75 Colun. L. Rev. 282, 299-313 (1975).

54 See notes $45-52$ supra \& accompanying text.

55 Bork, supra note 53, at 205-06 (arguing that mergers up to $60 \%$ or $70 \%$ of a market should be permitted, but interpreting Congress' wish to prevent $30 \%-40 \%$ combinations); Posner, supra note 53, at 312-13 (advocating that position and citing economic and legal literature in its support).

56 The theoretical justification for that view appears to be that in less concentrated markets, non-conspiratorial uniform behavior either will not occur or, if it does, can be challenged by a more imaginative application of cartel theory in actions 
The four-firm/sixty-percent line seems roughly equivalent to the standard governing merger enforcement under the Sherman Act or under section 7 of the Clayton Act prior to its amendment. ${ }^{57}$ Given Congress' clear intention in amending the Clayton Act to reach far beyond Sherman Act limits as interpreted in United States v. Columbia Steel Co. ${ }^{58}$ other commentators defend an anti-merger rule at a lower threshold level. If the "incipiency" dimension of section 7 is taken into account, and if it is recognized that it is virtually impossible as a matter of economics to describe precisely at what point concentration produces conditions that facilitate collusion, one can persuasively argue that the threshold level ought to be well below the four-firm/sixty-percent level.59 Even so, it is extremely difficult to defend, strictly on economic grounds, outlawing the kind of five-to-ten-percent horizontal mergers in Brown Shoe v. United States, ${ }^{60}$ United States $v$. Von's Grocery, ${ }^{61}$ and United States v. Pabst Brewing Co. ${ }^{62}$

The Supreme Court's position in those cases is comprehensible only if one recalls Congress' concern about the political consequences of what it believed was a rising tide of concentration. Obviously, no particular merger will threaten to produce a nondemocratic political order or generate an unacceptable level of private corporate discretion; it was the general trend that Congress perceived and that it regarded as a threat to political values. Moreover, it does not seem an adequate answer to say that if solely political concerns were at issue it would be enough to outlaw mergers among companies accounting for large market shares-not five-percent mergers in the retail trade. Whether right or wrong on the underlying facts, Congress was concerned with a trend-a

for conspiracy under section 1 of the Sherman Act. See Posner, Oligopoly and the Antitrust Laws: A Suggested Approach, 21 Stan. L. Rev. 562 (1969).

57 See United States v. First Nat'l Bank \& Trust Co., 376 U.S. 665 (1964) (violation of the Sherman Act was found with respect to a merger of the first and fourth largest commercial banks in a city, with a combined share of about 50\%, and with the top four firms accounting for about $80 \%$ of assets, deposits, and loans); United States v. Columbia Steel Co., 334 U.S. 495 (1948) (no violation of the Sherman Act when combined market share in the horizontal line was 24\%).

58334 U.S. 495 (1948). See H.R. Rep. No. 1191, 81st Cong., 1st Sess. 8-9 (1949). The Senate committee expressly stated that "the bill is not intended to revert to the Sherman Act test. The intent here . . . is to cope with monopolistic tendencies in their incipiency and well before they have attained such effects as would justify a Sherman Act proceeding." S. Rep. No. 1775, 81st Cong., $2 d$ Sess. $4-5$ (1950).

59 See, e.g., Sullivan, supra note 15, at 620-21.

60370 U.S. 294 (1962).

61384 U.S. 270 (1966).

62384 U.S. 546 (1966). 
dynamic process-that it believed had to be checked early, before it developed irresistible political momentum, to preserve fundamental democratic values. Although some of these cases push to the extreme the goal of stopping trends toward concentration, Congress was aware that much concentration in the country had occurred as a result of prior failures to deal with merger trends and apparently was prepared to pay a price to ensure that those failures would not continue.

Antitrusters who emphasize a political dimension in antitrust need not agree with the result in individual cases, including those that expressly cite political factors. In Von's Grocery, ${ }^{63}$ a merger between the third and sixth-ranked retail food sellers in Los Angeles, with a combined market share of $7.5 \%$, was struck down even though entry was easy and the market only moderately concentrated, on grounds that (l) there was a pronounced trend toward concentration underway, and (2) to protect small dealers ("worthy men") from being driven out of business. ${ }^{64}$ Even political antitrusters can regard that result as dubious. During the same period in which the number of single store outlets had fallen sharply, the number of chains increased from ninety-six to 150 , and the market share of the top two chains declined from twenty-one percent to fourteen percent. ${ }^{65}$ Thus, the trend among those companies that might have been induced to engage in cartels or drift into patterns of tacit collusion-that is, the top firms in the market-was toward deconcentration rather than concentration. Also, entry barriers were low and existing concentration moderate. Finally, the political values that the Court espoused-protection of small businessmen against the rigors of competition from larger, more efficient rivals-would not be served by preventing mergers among relatively small firms near the top of a loosely concentrated market. ${ }^{.6}$

\section{Treatment of a Defense Based on Redeeming Competitive Values}

When merging firms are relatively large in the markets in which they sell and the merger contributes significantly to market

63384 U.S. 270 (1966).

64 The concentration that concerned the Court arose from the fact that the number of single store retail grocery outlets in Los Angeles had decreased from 5,365 in 1950 to 3,818 in 1961. Id. 273.

65 Id. 281, 290-91 (Stewart, J., dissenting).

66 Id. 298 (Stewart, J., dissenting) (noting that the small businessman's "plight" in this market was that he was strong and secure and, indeed, was often the most aggressive competitor against larger chains). 
concentration, it is relatively easy to predict significant anticompetitive effects on the basis of non-political values. Those mergers facilitate the organization of explicit cartels and increase the likelihood of inter-firm patterns of coordinated competitive behavior. Nevertheless, defense counsel will frequently argue that despite the reduction in competition in some narrow product or geographic market, the merger allows the combined firm to compete effectively in a different and usually more significant product or geographic market.

United States v. Philadelphia National Bank $[P N B]^{67}$ presents a classic example of that kind of issue. The merging firms there were the second and third largest commercial banks in the fourcounty Philadelphia metropolitan area; their combined market share after the merger would have been about thirty percent, and the twofirm concentration ratio in the market would have increased from forty-five to sixty percent. ${ }^{68}$ Defendants argued that the increased lending limit of the resulting bank would have enabled it to compete with the large New York banks for national loans, and the injection of additional competition in that national market more than compensated for any reduction of competition in the Philadelphia area. ${ }^{69}$

The argument in defense of the merger certainly does not appear frivolous. In terms of national economic policy, and taking account the ability of banks, by control of credit, to influence competitive initiatives, it may very well be in the long run that additional competition for loans to nationally significant companies would be a major pro-competitive development. And even if the defendants were incorrect on the facts in Philadelphia National $B a n k$, there are bound to be many cases in which a lessening of competition in some narrow market is counterbalanced by increases in competition in a different larger market. Nevertheless, the Court refused to consider the contention, noting simply that an exception for redeeming competitive effects in another market would create a loophole in section 7 enforcement that could lead to unacceptable industrial concentration. ${ }^{70}$

67374 U.S. 321 (1963).

68 Id. $364-65$.

69 Id. 370-71.

70 "If anticompetitive effects in one market could be justified by pro-competitive consequences in another, the logical upshot would be that every firm in an industry could, without violating $\$ 7$, embark on a series of mergers that would make it in the end as large as the industry leader." Id. 370 . 
This issue of the relevance of compensating competitive effects is a difficult, close, vexing question of antitrust policy. The result in Philadelphia National Bank can be defended on grounds that do not implicate political considerations-specifically, that competitive advantages and disadvantages are difficult enough to measure, but that it is virtually impossible to incorporate any such measurements into a formula that will permit a conclusion with respect to the net effect on the economy. But it is questionable whether that calculation is really any more difficult than the measurement of tradeoffs that are characteristic of rule of reason areas, such as balancing business reasons for an exclusive dealing contract against the anticompetitive consequences of market foreclosure, ${ }^{71}$ or weighing the immediate pro-competitive effect of introducing by joint venture a new competitor into a product area against the loss to the competitive process of a "sidelines pro-competitive effect" because one of the parents, but for the joint venture, might have remained at the edge of the market contemplating independent entry. ${ }^{72}$ Calculation of pro- and anti-competitive effects would be no more difficult with respect to the $P N B$ "redeeming competitive effects issue" than in these other areas. The difference is that the $P N B$ rule, as much as any rule in merger enforcement, has contributed to the success of a policy aimed at preventing loose oligopolies from being converted by merger into tight oligopolies, and that policy of containment is central to the legislative purpose of revised section $7 .^{73}$

\section{Admissibility of Evidence of Efficiencies}

Advocates of differing views of the appropriate treatment of evidence of efficiency in merger litigation do not fall neatly into schools. Some commentators who have criticized the narrow economic approach would take clear evidence of efficiencies into account in close cases; "74 others who criticize "social theories" of antitrust enforcement would exclude evidence of economies of scale or managerial efficiencies because they are "intractable subjects for litigation." 75

71 See Tampa Elec. Co. v. Nashville Coal Co., 365 U.S. 320 (1961); Standard Oil Co. v. United States [Standard Stations], 337 U.S. 293 (1949).

72 See United States v. Penn-Olin Chem. Co., 378 U.S. 158 (1964).

73 See note 58 supra.

74 See, e.g., Blake \& Jones, supra note 1, at 456-57; Sullivan, supra note 15, at 631.

75 Posner, supra note 53, at 313. See also Turner, Conglomerate Mergers and Section 7 of the Clayton Act, 78 HARv. L. REv. 1313, 1339 (1965) (advocating exclusion of evidence of efficiencies on a case-by-case basis but taking such evidence into account in fashioning general merger rules-an approach similar to the one taken here). 
The case for exclusion of specific evidence of economies in defense of a merger can be expanded beyond consideration of the difficulties of handling such evidence in trial. First, there is the question whether any such efficiencies, assuming they do result from a consolidation of firms, could be achieved between firms by contract or by some sort of joint venture limited in scope and duration. Either alternative would leave the acquired firm free to pursue independent competitive policies unrelated to achievement of efficiencies. Second, if efficiencies are significant, it is likely that firms will expand or modify their operational techniques in order to achieve them internally. Viewed in this light, mergers may accelerate the achievement of certain kinds of economies, but the mergers are not essential to achieving those economies. Finally, it seems fair to inquire whether the efficiencies will be taken out in the form of increased profits for shareholders, or will be used by the company to compete more aggressively and place pressure on rivals to adopt and implement equivalent efficiencies. Assuming litigation occurs fairly promptly after the merger is inaugurated, it seems unlikely in most instances that there will be reliable evidence of what use will be made of savings introduced as a result of the merger.

When each of those factors is added to considerations of complexity, expense, and delay in litigation caused by the introduction of efficiency questions, a persuasive case begins to emerge either for excluding efficiencies entirely-which seems to be the present view of the law-or accepting such evidence only in close, exceptional cases.

Does a rule excluding evidence of efficiencies in merger litigation reflect "political" considerations? As noted, exclusion can be justified on other grounds, but it can also reflect an essential notion of the political goals of antitrust-that the matter of efficiencies is not dispositive, and that an occasional loss of efficiency as a result of antitrust enforcement can be tolerated and is to be expected if antitrust is to serve other legitimate values. As Justice Brandeis wrote:

The only argument that has been seriously advanced in favor of private monopoly is that competition involves waste ....

Undoubtedly competition involves waste. What human activity does not? The wastes of democracy are among the greatest obvious wastes, but we have com- 
pensations in democracy which far outweigh that waste and make it more efficient than absolutism. ${ }^{76}$

Clearly, the Supreme Court in the 1950's and 1960's believed that Congress preferred less concentrated market structures, including situations in which there could be an efficiency loss and the likelihood of cartelizing tendencies was remote. Even if a narrow exception for evidence of efficiencies were permitted-when the likelihood of competitive injuries was slight, the predicted efficiencies were capable of clear demonstration in court, and there was some likelihood that the efficiencies would be converted into significant competitive effects-that would still reflect an essentially "political" determination to pay an economic price to serve noneconomic goals. That position seems to be a valid interpretation of Congress' will.

\section{ConcLusion}

This paper has argued that the trend toward use of an exclusively economic approach to antitrust analysis excludes important political considerations that have in the past been seen as relevant by Congress and the courts. Such considerations as the fear that excessive concentration of economic power will foster antidemocratic political pressures, the desire to reduce the range of private discretion by a few in order to enhance individual freedom, and the fear that increased governmental intrusion will become necessary if the economy is dominated by the few, can and should be feasibly incorporated into the antitrust equation. Although economic concerns would remain paramount, to ignore these non-economic factors would be to ignore the bases of antitrust legislation and the political consensus by which antitrust has been supported.

76 L. Brandets, The Curse of Bigness 105 (1934), quoted in United States v. Columbia Steel Co., 334 U.S. 495, 534-35 n.1 (Douglas, J., dissenting). 